\title{
Microbiopolítica e regulação sanitária: desacordos entre ciência e saberes locais na produção dos queijos minas artesanais
}

\section{Microbiopolitics and sanitary regulation: disagreements between science and local knowledge in the production of artisanal cheese in Minas Gerais}

\author{
Rosângela Pezza Cintrão* \\ * Universidade Federal Rural do Rio de Janeiro - Rio de Janeiro, RJ, Brasil \\ Pesquisadora associada ao Centro de Referência em Soberania e Segurança \\ Alimentar e Nutricional \\ bibicintrao@gmail.com \\ https://orcid.org/0000-0002-4549-8549 \\ Leonardo Vilaça Dupin** \\ ** Universidade Estadual de Campinas - Campinas, SP, Brasil \\ Pesquisador associado ao Centro de Estudos Rurais \\ leodupin@hotmail.com \\ https://orcid.org/0000-0001-9013-187X
}




\title{
Resumo
}

Este artigo analisa a relação da produção de queijos artesanais em Minas Gerais com imposições da regulação sanitária, configuradas em instrumentos e mecanismos de biossegurança, conformados em mercados internacionais, que constroem uma imagem da produção de queijos feitos nas roças, fortemente enraizados culturalmente, como "atrasada" e "anti-higiênica". As normas sanitárias exigem a contratação de responsáveis técnicos (engenheiros de alimentos, veterinários, nutricionistas) e consideram a formação técnica e a produção em moldes industriais como intrinsecamente mais seguras. E, em sentido contrário, criam suspeitas que populações camponesas estejam produzindo alimentos contaminados e inseguros. Ao converterem seres microscópicos em ameaça à sociedade, tais normas se constroem com uma microbiopolítica, constituindo-se como fonte de poder que associa moralmente pobreza e risco. E criam barreiras à comercialização das produções camponesas, interferindo em seus modos de vida. Baseado em trabalhos etnográficos, o artigo aborda como essas populações interagem com algumas das prescrições das normas sanitárias e conhecimentos técnico-científicos, que chegam a elas através da atividade de fiscais sanitários e de técnicos ligados à extensão rural.

Palavras-chave: queijos artesanais; microbiopolítica; laboratório; vigilância sanitária.

\begin{abstract}
This article focuses on the relations between artisanal cheese production in Minas Gerais and the imposition of bio-safety policies and practices that have been structures in international markets and global science structures. It analyzes how sanitary regulation has contributed for an image of cheese production in the countryside, with its strong cultural roots, as "archaic" and "un-hygienic", seen with suspicion by urban and "modern" societies. The implementation this regulation presents industrial food production as more efficient and safer, at the same time building suspicions that peasants are producing contaminated and unsafe food. These sanitary norms convert microscopic beings as a threat to society and constitute a microbiopolitics that is a source of power, morally connecting poverty and risk. This process has created strong barriers to legalizing peasant products, interfering on their life ways.
\end{abstract}

Keywords: artisanal cheese; microbiopolitics; laboratory; sanitary inspection. 


\section{Introdução}

$\mathrm{Na}$ época estavam em funcionamento no imenso território brasileiro um número impreciso de queijarias, praticamente apenas na zona rural. Talvez elas passassem de mil em sua anônima multiplicação artesanal. Os queijos iam para o mercado sem embalagens, marcas, rótulos, nomes dos fabricantes. Máquinas, higiene, transporte, zero. Retratos de um Brasil desprovido de energia elétrica, de estradas decentes, de tradição e cultura de laticínios. [...] Nas "casas de queijos" da roça o trabalho, sempre igual na sua rotina de nenhum compromisso, ficava a cargo das mulheres e das crianças. $\mathrm{O}$ atraso estava prestes a mudar [...] As queijarias em estágio mais avançado que vieram a seguir pegaram carona no primeiro surto industrial do Brasil, ocorrido nas décadas de 1880 e 1890. (Dias, 2010, p. 73).

O início da era industrial, associado ao processo de urbanização, foi acompanhado por uma verdadeira obsessão pela higiene, que se refletiu em muitos aspectos da vida, desde o saneamento das cidades até os hábitos cotidianos. No campo da alimentação e da conservação de alimentos, o industrial (associado ao urbano) se desenvolve sob o signo da eficiência e da higiene, enquanto o fazer artesanal (e rural) adquire a conotação de "atrasado" e, mesmo, "sujo" e "anti-higiênico", passando a ser olhado com desconfiança pelas sociedades urbanas ditas modernas. Os olhares dominantes sobre a produção de queijos na zona rural, como o da citação acima, são um exemplo de concepções fortemente associadas à imagem da produção industrial como modelo a ser seguido.

No entanto, a emergência de queijos industriais e a instalação de grandes e médios laticínios, que coletam leite nas zonas rurais e o direcionam a indústrias nas cidades, não afastaram completamente a fabricação de queijos do âmbito da produção camponesa. Esse é o caso de várias regiões de Minas Gerais, onde persistem, no "anonimato" (sem marcas, rótulos, nomes de fabricantes), milhares de unidades produção artesanal de queijo em pequena escala, em zonas rurais de regiões montanhosas de difícil acesso, mantendo relações específicas com os territórios ocupados e seus recursos naturais. Inseridas em circuitos informais de comercialização, são importantes para a economia de vários municípios mineiros com perfil marcadamente rural. Resistindo à forte oligopolização na indústria agroalimentar, esta produção permanece como um 
setor pouco concentrado, com a maioria dos insumos sendo locais. Está associada à família e a modos de vida, ao compartilhamento de saberes e fazeres, como dádiva e expressão da moralidade, que vai além de uma simples produção de mercadorias e bens passíveis de alienação.

Os queijos artesanais permanecem até hoje enraizados nas culturas alimentares de suas regiões, tornando-se um alimento transversal, inserido no cotidiano em cafés da manhã, almoços e jantares e em receitas como a do pão de queijo. Mas também extrapolam as fronteiras locais e são vendidos em vários centros urbanos de Minas Gerais e dos estados vizinhos. Sua grande popularidade permite até hoje uma relativa independência, tanto em relação à indústria de insumos quanto aos laticínios. Como disse uma liderança da região da Canastra: "O queijo é um dos poucos segmentos hoje em dia em que o produtor consegue dominar todo o processo, inclusive a alimentação das vacas."

Porém, a partir dos anos 1990 a continuidade de sua produção começou a ser ameaçada por ações fiscalizatórias mais agressivas, que buscam impedir a sua comercialização informal, que passa a ser cada vez mais ilegalizada, criando um espaço discursivo que suscita suspeitas de serem alimentos contaminados e potencialmente perigosos para a saúde humana. Multas e apreensões pelo não cumprimento da legislação sanitária buscam reforçar a profecia de que os queijos artesanais feitos nas roças estariam fadados a desaparecer, suplantados pela superioridade da indústria de laticínios.

Como reação, a importância cultural do alimento foi evocada em sua defesa, alcançando o reconhecimento legal de seu valor e apreciação, com o registro como bem cultural imaterial, pelo Instituto do Patrimônio Histórico e Artístico Nacional (Iphan), do "modo de fazer os queijos minas artesanais" em algumas regiões com concentração dessa produção, como Serro, Serra da Canastra e Serra do Salitre/Alto Paranaíba. Houve ainda a implementação de certificações como as Indicações Geográficas, inspiradas no modelo francês, que atribuem um selo de qualidade a produtos comerciais identificados com um território e com uma forma de produção, reconhecidos por sua notoriedade. ${ }^{1}$ Mas, apesar

1 Atualmente duas regiões - Canastra e Serro - possuem Indicação Geográfica. Garcia-Parpet (2016) observa que a França foi pioneira na proteção de seus produtos com essa valorização institucional, que propiciou que produtos locais mudassem de status, passando de um produto commodity a um produto simbólico. 
do efeito simbólico de valorização dessa produção, nem mesmo esses reconhecimentos legais resolveram os problemas com as leis sanitárias, que permanecem como fortes barreiras comerciais e de reprodução de modos de vida de famílias produtoras de origem camponesa.

Este artigo, baseado em trabalhos etnográficos nas regiões produtoras acima mencionadas, busca abordar como essas populações interagem com as normas sanitárias e conhecimentos técnico-científicos, que chegam a elas através de fiscais sanitários e de técnicos ligados à extensão rural. Analisamos as diferentes percepções e implicações da legislação, assim como seu reforço à dominação simbólica (no sentido de Bourdieu, 1989) de uma estética urbana e industrial, que aponta para alimentos produzidos na zona rural por populações de perfil camponês como potencialmente mais "sujos" e "perigosos".

Apontaremos como a regulação sanitária dos alimentos, apesar de se construir sob a ótica da objetividade, cientificidade e impessoalidade, com a justificativa de "proteção da saúde da população", se apresentando como puramente científica (e, portanto, "neutra"), embute um conjunto de práticas biopolíticas (Foucault, 2005, 2008) e avaliações culturais e morais ancoradas numa percepção colonial ${ }^{2}$ que têm gerado, por efeito, o favorecimento modelos e valores industriais de produção em grande escala, fazendo emergir resistências e controvérsias relacionadas a questões sociais, mas também sobre "alimentos seguros".

2 No sentido colocado por Escobar (1995) e Ribeiro (2008).

3 Há uma disputa de sentidos e classificações em torno da noção de "alimento seguro", associada às noções de "risco" e "perigo", assim como de "segurança do alimento", às vezes confundida com "segurança alimentar". Cruz e Schneider (2010) e Cintrão (2017) observam que a expressão "segurança do alimento" (food safety, em inglês) se refere a normas sanitárias (CodexAlimentarius), que estabelecem padrões sanitários de qualidade com base em estudos científicos, considerados como neutros e universais. Essas normas são construídas no âmbito do comércio internacional, voltadas para a produção industrial de grande escala e para as exportações, levando a uma forte padronização de processos e produtos. Já o termo "segurança alimentar" (food security), que surge relacionado a questões de pobreza e fome, também com definições internacionais no âmbito das Nações Unidas, passou a incorporar na sua definição a questão das "práticas alimentares promotoras de saúde", que abrange as dimensões cultural, social, econômica e ambiental (Cintrão, 2017; Cruz; Schneider, 2010). Neste artigo, quando falamos de "alimentos seguros", estamos nos reportando principalmente às definições das normas sanitárias (food safety). 


\section{Lei estadual para o queijo minas artesanal, exames laboratoriais e ilegalizações}

Por que a questão do queijo nos preocupa? [...]. Esse problema do queijo é crônico. Desde 1984, temos sucessivos problemas relacionados ao queijo. [...] O que se analisa dá problema. [...] Analisamos 35 queijos: queijo minas, frescal, padrão, canastra e serro. Nesses, $71 \%$ foram condenados nas análises microbiológicas. Desses $71 \%$, o que faltou dos $100 \%$ são daqueles produtos que sofriam inspeção. Lamentavelmente, nos produtos que não eram inspecionados, tivemos 100\% de condenação. (Representante da Vigilância Sanitária Estadual em audiência pública sobre os queijos artesanais - Assembleia Legislativa, MG, 2001, cf. Cintrão, 2016, p. 54).

Na década de 1990, multiplicam-se trabalhos científicos que coletam amostras de queijos em feiras e mercados e verificam, em laboratório, a presença de quatros grupos de microrganismos estabelecidos por códigos internacionais, como "indicadores de qualidade sanitária". A presença de algum desses seres microscópicos acima dos níveis legais classifica os produtos como "impróprios ao consumo humano", performando uma realidade de "falta de segurança alimentar" (food safety) e de condenação da quase totalidade dos queijos comercializados informalmente, que justifica as ações fiscalizatórias, mas revela uma forte incongruência entre a realidade performada pelo laboratório e as avaliações dos consumidores, que os consideram alimentos inócuos e saborosos. ${ }^{4}$

Em 2001, uma grande apreensão de queijos no Mercado Central de Belo Horizonte - um dos maiores pontos de sua comercialização em Minas Gerais - gerou fortes reações, tendo em vista a defesa das famílias produtoras e das tradições culinárias mineiras. As negociações resultaram na aprovação, em 2002, de uma lei estadual de exceção, voltada para o que passa a ser chamado

4 Vale observar que o consumo destes queijos $100 \%$ condenados não é insignificante. Dados da Emater-MG de 2002 estimavam a produção estadual em 3.600 toneladas por mês (120 toneladas por dia) (Cintrão, 2016). 
de "queijo minas artesanal" ${ }^{5}$ Essa foi a primeira lei no Brasil a admitir a elaboração de queijos com leite cru (não pasteurizado), ${ }^{6}$ permitindo sua comercialização dentro daquele estado e desafiando o Riispoa (Regulamento de Inspeção Industrial e Sanitária de Produtos de Origem Animal), lei federal sob responsabilidade do Ministério da Agricultura e Pecuária (Mapa), que exige que todos os queijos sejam de leite pasteurizado. Por esta razão, o Mapa inicialmente não reconheceu a lei estadual para efeitos de comercialização interestadual.

Apesar do reconhecimento das qualidades gastronômicas dos queijos artesanais, a nova legislação estadual desencadeou um conjunto de ações voltadas para provar e/ou melhorar a sua qualidade sanitária, tendo em vista ajustá-la aos parâmetros da legislação, com o engajamento de produtores, comerciantes, poder legislativo, universidades e órgãos de pesquisa, agências sanitárias, órgãos de extensão rural, com destaque para a Emater-MG (órgão de extensão rural) e o IMA (órgão responsável pelo registro sanitário). ${ }^{7}$ Todo esse processo é permeado por inúmeras controvérsias, não somente entre os atores, mas também internamente a cada segmento, como no caso dos órgãos sanitários estadual e federal.

Por um lado, a lei estadual atendeu a uma das principais preocupações dos que vinham em defesa dos queijos minas artesanais: a não imposição da pasteurização do leite, que descaracteriza o queijo e inviabiliza economicamente as produções em pequena escala. Por outro lado, essa mesma lei impôs tempos mínimos de maturação dos queijos que entram em choque com os hábitos de consumo e com a forte preferência dos consumidores pelos queijos ainda brancos, não maturados. Para além disso, traz inúmeras restrições e um amplo conjunto de exigências, de diferentes ordens, que levam a grande maioria das famílias camponesas produtoras do alimento em Minas Gerais a permanecer

5 A lei estadual $n^{\circ}$ 14.185/2002 (Minas Gerais, 2002), que foi construída inspirada na experiência francesa.

6 A expressão "queijo de leite cru", que não é uma expressão local, é utilizada para diferenciá-los dos queijos industriais feitos com leite submetido a tratamentos térmicos, como a pasteurização, fortemente recomendada por códigos sanitários mundiais como o Codex Alimentarius e alvo de fortes controvérsias internacionais (West, 2008), dado que até o início do século XX todos os queijos existentes eram fabricados com leite cru e os tratamentos térmicos alteram suas propriedades de sabor e textura.

7 Respectivamente: Empresa de Assistência Técnica e Extensão Rural de Minas Gerais e Instituto Mineiro de Agropecuária, ambos vinculados à Secretaria de Agricultura. 
na informalidade. ${ }^{8}$ As dificuldades para a sua legalização revelam uma forte dissociação entre a legislação e as formas de produção camponesa que deram aos queijos seu reconhecimento.

No entanto, se antes da existência da lei estadual toda a produção e comercialização desses queijos se dava de maneira informal, a partir dela gera-se uma distinção entre produtores "cadastrados" - que buscam se legalizar - e "não cadastrados" - que permanecem à margem da lei -, gerando processos de ilegalização. ${ }^{10} \mathrm{~A}$ estratégia de adoção das Indicações Geográficas atrairia instituições e atores - incluindo novos produtores - que buscam a legalização e a construção mercados de elite para esses queijos, agravando a ilegalização, especialmente das famílias de perfil camponês. ${ }^{11}$

\section{Microbiopolítica e agentes invisíveis: instrumentos da ordem da segurança trazem concepções urbanas e industriais para as roças}

Mesmo que a lei estadual e suas normatizações tenham surgido em defesa da produção artesanal de queijo, a referência a normas construídas no âmbito do mercado internacional (como o Codex Alimentarius) coloca a necessidade de vigiar e disciplinar cada mínimo detalhe da produção dos queijos, tendo como modelo a produção industrial. A regulação sanitária envolve complexos emaranhados legais e institucionais, da escala global à local, configurando-a como uma biopolítica (Foucault, 2005, 2008), numa governamentalidade que conjuga dispositivos jurídico-legais (proibições), mecanismos da ordem da vigilância

8 Com base em dados da Emater-MG e do IMA, Cintrão (2016) estima que em 2014 apenas 0,5\% das cerca de 30 mil famílias produtoras de queijos artesanais em Minas Gerais haviam se cadastrado. Mesmo dentro das principais regiões produtoras o número de cadastrados não chega a $5 \%$.

9 O termo refere-se ao cadastramento das famílias produtoras no IMA, órgão estadual responsável pelo registro sanitário.

10 Cintrão (2016) observa que as esferas "formal" e "informal" não estão inteiramente separadas, e a existência de uma legislação (e mesmo da repressão) não garante que uma atividade seja considerada como legal ou ilegal pelos diferentes setores da sociedade: a lei precisa ser acompanhada de processos de legitimação e/ou de ilegalização.

11 Cintrão (2016) e Dupin (2019) analisam essas questões. 
(que buscam prescrever nos mínimos detalhes como deve ser a produção) e instrumentos da ordem da segurança (que colocam em cena o laboratório ${ }^{12}$ ), que visam governar à distância a atividade econômica, a vida social e a conduta de pessoas e microrganismos, à luz de determinadas concepções do que é bom, saudável, normal, virtuoso, eficiente e lucrativo. ${ }^{13}$

E uma análise mais detida dessas normatizações aponta que essas concepções estão voltadas para um modelo de produção hegemônico que, conforme observam Cruz e Schneider (2010), associa a produção de alimentos a estruturas industriais e a produções cada vez mais automatizadas, voltadas para aumentos de escala e de produtividade, em contextos de elevada urbanização, visando conservar, armazenar e distribuir alimentos em massa a locais cada vez mais distantes. Nesse contexto, a produção de conhecimentos científico-tecnológicos e a legislação sanitária estão fortemente voltadas para evitar contaminações, associando "segurança" e "qualidade sanitária" com ausência de microrganismos. E, em seu cumprimento, exigindo instalações, procedimentos, equipamentos e utensílios que permitam maior esterilização, padronizando processos e produtos.

As legislações sanitárias para os alimentos compõem um modelo de significação, produzido por especialistas, constituindo-se num aparato, fundado nas ciências biológicas, que parte da premissa de uma guerra contra seres invisíveis e misteriosos, em que cabe aos cientistas (através dos laboratórios) explicar a realidade oculta e enfrentar o inimigo (Latour, 1993)..$^{14}$ Apoiadas em modernas

12 Entre as exigências da legislação estadual estão análises laboratoriais periódicas dos queijos e das pessoas que os produzem, um dos elementos de legitimação das normas sanitárias.

13 O surgimento da vigilância sanitária, no final do século XIX, se dá juntamente com a constituição das ciências modernas, com a instalação de uma nova arte de governar que conforma o Estado moderno (no sentido weberiano do termo) e se ancora numa relação bem particular entre o poder e o saber, com o conhecimento científico se tornando cada vez mais indispensável para um "bom governo" e para a legitimação essencial do poder do Estado (Foucault, 2008).

14 Latour (1993), analisando os trabalhos de Pasteur no século XIX, chama a atenção para a "agência" de seres microscópicos, que se interpõem entre os humanos, redefinindo os vínculos sociais que, na época, se acomodavam à recente colocação em cena do laboratório e da vida microbiana. Enquanto Foucault $(2005,2008)$ analisa a biopolítica em suas técnicas e instrumentos de governo e racionalidade, Latour se pergunta em que condições a agência dos micróbios permite aos cientistas passar da observação em laboratórios para o espaço público. Latour está interessado não apenas na aplicação de um dado poder sobre os corpos, mas na composição prévia de uma imprevisível fonte de poder. Argumenta que somente depois de um processo de convencimento - inclusive sobre a própria existência desses seres - é que a higiene tornou-se um "poder" $\rightarrow$ 
tecnologias, buscam prever e ordenar racionalmente a realidade, menosprezando fatores culturais, investindo contra os instrumentos de trabalhos locais (tomados como arcaicos) e exigindo modificações no ambiente e nas condutas. Impõem definições de padrões alimentares que partem de noções de "higiene", "risco" e "perigo", tomadas como científicas e neutras, mas que carregam forte carga simbólica, exprimindo uma ideia genérica de ordem e desordem (Douglas, 1976), associada ao modelo urbano e industrial. ${ }^{15}$

Entre os principais dispositivos biopolíticos está a exigência periódica das análises laboratoriais para a verificação dos "indicadores de qualidade microbiológica". Nos queijos minas artesanais, a "segurança do alimento" (food safety) é verificada pela presença de quatro grupos de microrganismos: salmonelas, listerias, coliformes fecais e estafilococos. ${ }^{16}$ Os elevados índices de "condenação" dos queijos, que atestam sua "falta de segurança", se dão em geral pela presença, acima do permitido, de coliformes ou estafilococos, considerados também como "indicadores de higiene". Os níveis máximos permitidos, voltados para produções industriais de grande escala, ${ }^{17}$ ajudam a construir uma imagem dos queijos (e das pessoas que os produzem) como "sujos" e "anti-higiênicos", associando-os a riscos e perigos.

$\rightarrow$ para disciplinar e coagir. E que foram importantes setores profissionais, como os sanitaristas, que acolheram as descobertas dos pasteurianos, pois permitiam direcionar e aumentar a eficácia de sua ação. Nesse processo, lei científica, lei jurídica e moralidade pública se reforçaram mutuamente para combater os micróbios e possibilitar a regeneração social das massas urbanas. O que Pasteur descobriu não foram os micróbios, mas como controlá-los em laboratório e conectá-los ao Estado republicano (Latour, 1993).

15 Os queijos tradicionais (não pasteurizados) são talvez o alimento que suscite as maiores reações e controvérsias a essa lógica, pois as exigências sanitizantes alteram suas características de consistência e sabor, descaracterizando-os. Isso porque são "alimentos vivos", ou seja, com forte presença de bactérias (lactobacilus) e fungos que fazem com que estejam em constante performance, reagindo a interferências do ambiente externo.

16 Salmonelas, coliformes fecais e estafilococos são os três grupos de microrganismos mais associados a intoxicações alimentares.

17 Esses níveis máximos são definidos por especialistas, no âmbito de acordos internacionais de comércio. Por exemplo, a portaria $n^{\circ}$ 146/1996 (Brasil, 1996), do Mapa, que estabelece o "Regulamento Técnico de Identidade e Qualidade do Queijo" (uma das referências para a lei estadual do queijo artesanal), se reporta a resoluções do Mercosul, que por sua vez se referenciam no Codex Alimentarius e em normas estabelecidas no âmbito da Federação Internacional de Lácteos (normas FIL), com forte influência de grandes indústrias de laticínios (Cintrão, 2016). 
Percebe-se nas normas sanitárias uma certa obsessão pela ausência de microrganismos, numa determinada maneira de conceber a saúde que Paxson (2013) denomina como "pasteuriana". Analisando o ressurgimento dos queijos artesanais de leite cru nos Estados Unidos ${ }^{18} \mathrm{e}$ as controvérsias que ele suscita, a autora parte da noção foucaultiana de biopolítica e a associa à noção latouriana de "agência" de seres microbianos, cunhando o termo "microbiopolítica". Ela observa que a legislação sanitária envolve a criação e popularização de categorias de agentes microscópicos classificados, através de uma lente antropocêntrica, entre "bons" e "maus". Com base nisso, a lei promulga comportamentos e práticas humanas adequadas tendo em vista as relações entre seres humanos e microrganismos. Com isso, as práticas regulatórias voltam-se não apenas para a produção de "alimentos seguros", mas também para conduzir agentes públicos a decisões racionais para o estabelecimento de formas seguras de comer (como responsabilidade moral), construindo a "germofobia" como fonte de poder (Paxson, 2013).

Seguindo esse mesmo modelo de significação, a legislação mineira para os queijos e as ações voltadas para a sua implementação - sempre imbuídas do espírito de projetos de desenvolvimento (conforme Escobar, 1995) ${ }^{19}$ - fizeram chegar às famílias produtoras de queijos minas artesanais outsiders (fiscais sanitários, extensionistas e pesquisadores) vindos de grupos caracterizados por "forte espírito corporativo" e pela interiorização de valores "heroicos", enviados para compensar "deficiências" locais (Ribeiro, 2008), com poder de determinar as normas (do ponto de vista científico e jurídico) e de garantir seu cumprimento (como moralidade pública). ${ }^{20}$ Fruto da constituição de estereótipos

18 Onde profissionais de origem urbana e com formação universitária deixam suas carreiras para se tornar artesãos, voltando-se para mercados gourmets e para um público urbano de maior poder aquisitivo, num processo semelhante ao que acontece na região da Canastra e no Serro, analisado por Dupin (2019).

19 Escobar (1995) aponta como o conceito de desenvolvimento, relacionado a políticas públicas, constrói a ideia de que é necessário disseminar as características de sociedades "avançadas", como altos níveis de industrialização e urbanização, modernização da agricultura, crescimento rápido da produção material e dos níveis de vida.

20 Um processo que exclui a dimensão humana relacionada ao conhecimento prático local e foca exclusivamente na eficiência técnica, deixando de lado valores como criatividade, lealdade, confiança, reputação e representação (Escobar, 1995). Ribeiro (2008) observa que, antes da existência dos projetos de desenvolvimento, populações locais dificilmente poderiam imaginar que seu destino seria suscetível de ser sequestrado por um grupo organizado de elites técnicas que, nos termos de Foucault, exerceria sua dominação objetivando seu bem-estar e progresso. 
colonialistas, esses agentes tendem a atribuir às famílias produtoras - especialmente as de origem camponesa - uma "falta de higiene" e uma certa ignorância, considerando-as presas ao passado e sem êxito para ultrapassar seu estágio tradicional, rumo à condição moderna (Escobar, 1995), que tem a (grande) indústria como modelo a ser seguido.

No entanto, as populações (rurais e urbanas) das regiões produtoras dos queijos artesanais mineiros (que são também consumidoras) têm suas próprias noções de "qualidade" e "segurança", associadas a práticas de produção e consumo socialmente construídas e culturalmente enraizadas que, embora não estáticas, seguem lógicas diferentes e reagem às intervenções.

\section{Entre quartos de queijo e queijarias: exigências e alterações no modo de fazer}

Eu morava numa casa que estava caindo. Eu falei: como é que eu vou fazer para construir uma queijaria bem feita, que exige os padrões da lei e ficar morando nessa casa que está em tempo de cair em cima de nós? Como é que vou fazer? E eu nunca gostei de mexer em banco. Não gosto de dever, gosto de deitar, seja pobre ou com dinheiro no bolso, mas sabendo que ninguém vai me cobrar no outro dia. Aí eu tinha umas vacas muito boas, cobiçadas na época. Aí eu garrei e vendi as vacas. Pensei: com pouquinha renda na graça de Deus a gente vive. Aí eu fiz essa casinha (de queijo) para nós, com o dinheiro das vacas. Aí no outro ano eu já dei conta de fazer as instalações, colhi um cafezinho, eu tinha uma caminhonete e vendi ela. Ficamos eu e Maria andando na motinha velha, porque nós gostamos de rezar demais e aí nós ia para missa nessa motinha. Passei uma temporada grande sacrificado, mas construí a queijaria. [...] Financeiramente fiz o negócio mais péssimo da minha vida, mas não arrependo, não, porque tenho a consciência que estou mandando um alimento bem saudável para o consumidor. (Produtor da região da Canastra, 2016, cf. Dupin, 2019, p. 329).

Pelos custos econômicos que implicam - com necessidade de investimentos monetários e aumentos nos custos de produção -, as exigências sanitárias para as estruturas físicas dos cômodos de produção dos queijos minas artesanais se 
colocam como a principal barreira econômica para a legalização das produções em menor escala. ${ }^{21}$ São comuns histórias como a citada acima, de famílias produtoras que fizeram sacrifícios financeiros para adequar seu "quarto de queijo" à legislação e à sua noção de ordem. Ou que se endividaram e "quebraram", não conseguindo cobrir os custos e investimentos.

Nas regiões analisadas, os cômodos onde os queijos são produzidos eram chamados de "quartos de queijo" ou "casas de queijo", sendo condenados e convertidos em "queijarias", uma mudança que, para além da semântica, tem inúmeras implicações práticas. Interferem no modo de fazer, na vida das famílias e na própria "vida do queijo", trazendo dificuldades e resistências. Para além da questão econômica, as exigências de alteração colocadas pelas legislações sanitárias provocam um conjunto de mudanças na relação das famílias camponesas com a produção de queijo.

Vale ressaltar que, nessas regiões produtoras de queijos minas artesanais, a tecnologia para a elaboração do queijo minas artesanal - que fez a sua fama - permite às famílias produtoras transformar e conservar o excedente do leite via fermentação, em estruturas físicas bastante simples e baratas, sem necessidade de outras fontes de energia. Utiliza como ingredientes apenas o leite, coalho, sal e o fermento natural (chamado de "pingo"). ${ }^{22}$ Desde a alimentação do gado até o armazenamento, o "modo de fazer" permite a utilização de insumos e materiais encontrados nas próprias fazendas ou arredores, como o barro e as madeiras para as construções, equipamentos e utensílios. ${ }^{23}$

Há assim um conjunto de tecnologias socialmente construídas que faz com que até hoje essa atividade se mostre acessível à entrada de novas famílias camponesas na produção, incluindo jovens casais. Há uma incorporação

21 Apesar de se justificarem como proteção à saúde dos consumidores, a construção das normas sanitárias, desde os níveis locais ao global, está bastante imbricada com as disputas por mercados e vem crescentemente se colocando como uma estratégia a mais para a oligopolização de mercados (Cintrão, 2016).

22 O "pingo", rico em microrganismos endógenos, é recolhido do soro que "pinga", durante a noite, dos queijos produzidos no dia anterior.

23 Até o início do século $\mathrm{XX}$, o sal era o único elemento exterior às regiões produtoras. Mesmo o coalho era feito do estômago de alguns animais. As casas de queijo eram construídas em madeira, adobe, pau a pique ou bambu. 
de inovações (nem sempre reconhecida pelos técnicos especializados), mas seguindo uma lógica própria, que se aproxima do que Ploeg (2008) chama de "coprodução entre homem e natureza" e de busca de "autonomia na base de recursos", numa tendência que contraria a lógica concentradora das grandes corporações.

Com dispositivos de poder claramente da ordem da vigilância e da disciplina (nos termos de Foucault, 2005, 2008), a lei estadual e suas normatizações contêm várias páginas voltadas para definições, nos mínimos detalhes, de como devem ser as construções, equipamentos e utensílios para a produção do queijo. ${ }^{24}$ Ao tomar como parâmetro as produções industriais, as normas inviabilizam a legalização dos cômodos existentes, colocando a necessidade de construção de uma nova queijaria.

Mesmo buscado simplificar as exigências federais, a legislação estadual constrói uma imagem dos "quartos de queijo" como rudimentares e insalubres. Obriga que as construções sejam de alvenaria, com paredes azulejadas (fortemente recomendadas) ou pintadas com tintas especiais, com forros sintéticos no teto, pisos cimentados e calçados. ${ }^{25}$ Que tudo seja de cor clara, de preferência branco. Exige a separação do espaço interno da queijaria em diferentes "ambientes" ou "áreas": vestiário, produção, maturação e embalagem/ expedição.

Legitimando as práticas biopolíticas, falas e apresentações dos extensionistas e fiscais sanitários passam a mostrar fotos comparando as novas queijarias com as antigas casas de queijo, como prova das "melhorias" alcançadas, como nas Figuras 1 e 2, extraídas do site da Emater-MG.

24 Prescrições e interdições sobre "os requisitos básicos das instalações, materiais e equipamentos da queijaria artesanal" se encontram já no artigo $5^{\circ}$ da lei estadual $n^{\circ} 14.185 / 2002$ (Minas Gerais, 2002) e no capítulo VI da sua regulamentação e são mais detalhados nas portarias do IMA n $^{\circ} 518 / 2002$ e n523/2002 (Instituto Mineiro de Agropecuária, 2002a, 2002b), a primeira com três páginas e a segunda com dez páginas e cerca de 50 artigos tratando dessas questões, relacionando-as com as "condições higiênico-sanitárias e as boas práticas na manipulação e fabricação" (ver Cintrão, 2016).

25 Em geral as casas de queijo não têm forro ou este é de madeira ou de fibras naturais. E o piso normalmente é de terra batida ou com cores escuras. 
Instalações antes da implantação do Programa Queijo Minas Artesanal
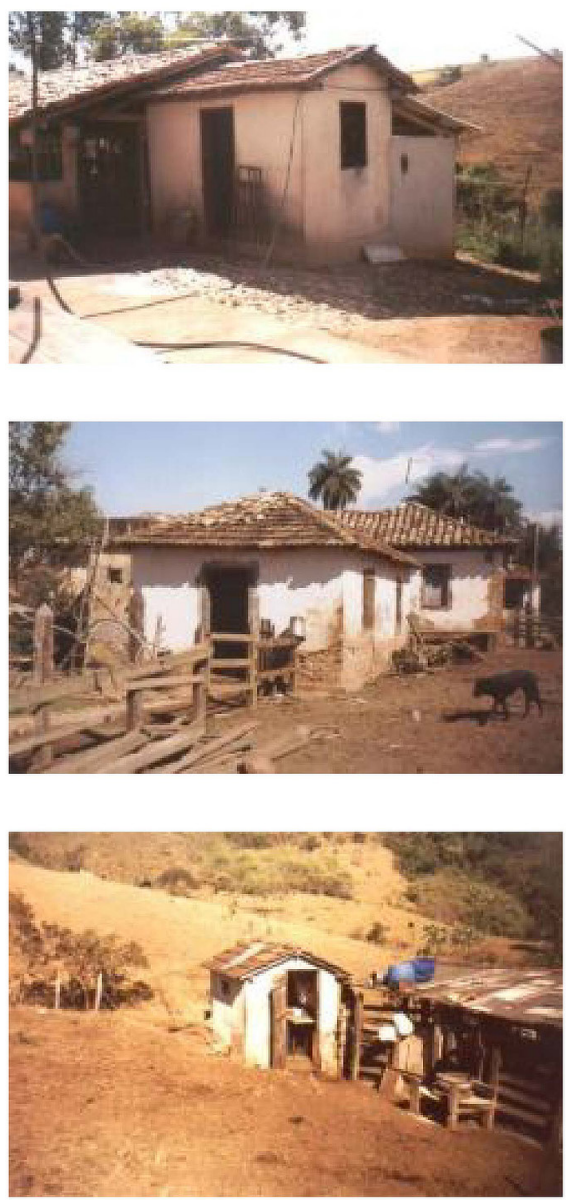

Instalações após a implantação do Programa Queijo Minas Artesanal
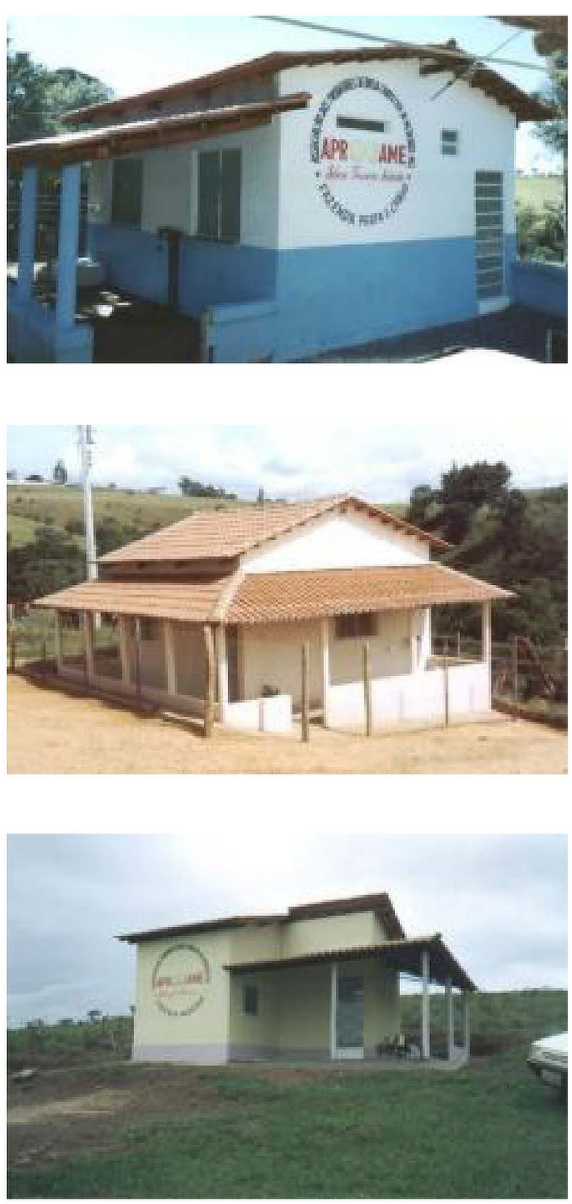

Figura 1. Fotos comparativas entre as antigas casas de queijo e as novas queijarias na região da Canastra - vista exterior.

Fonte: Site da Emater-MG. Programa Queijo Minas Artesanal - Melhoria das Instalações - região da Canastra (http://www.emater.mg.gov.br/portal.do?flagweb=site_tpl_ queijo\&id=3620), acessado em outubro de 2019 . 
Interior da queijaria antes da implantação do Programa Queijo Minas Artesanal
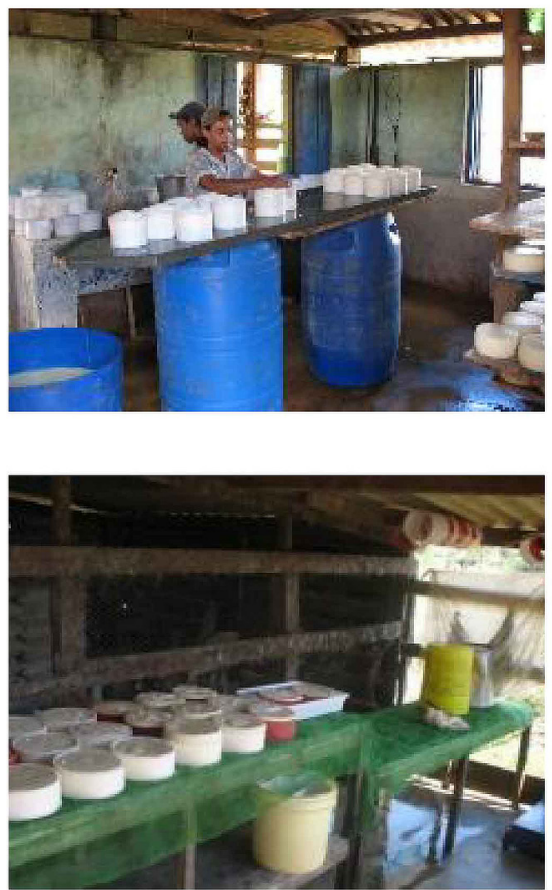

Interior da queijaria após a implantação do Programa Queijo Minas Artesanal
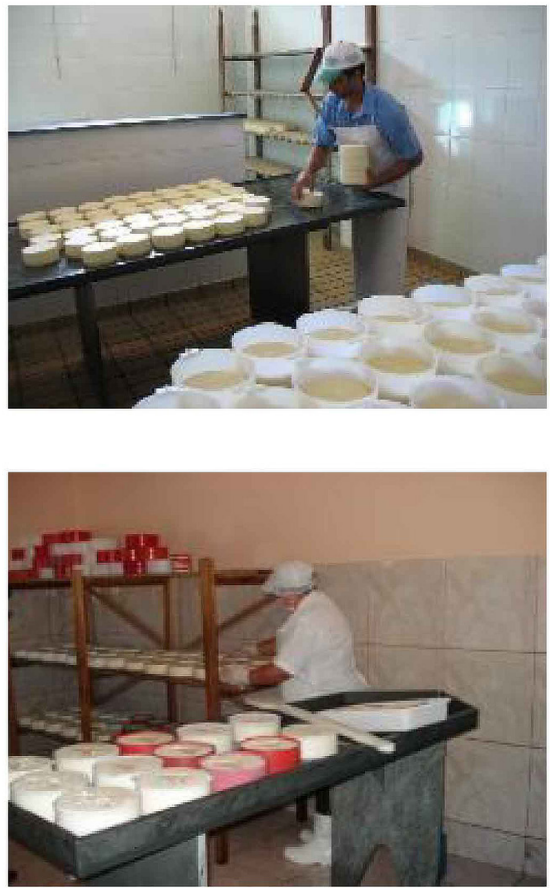

Figura 2. Fotos do interior das casas de queijo, "antes" e "depois" da adequação às normas sanitárias.

Fonte: Site da Emater-MG. Programa Queijo Minas Artesanal - Melhoria das Instalações - região Cerrado (http://www.emater.mg.gov.br/portal.do?flagweb=site_ tpl_queijo\&id=3621) e região Serro (http://www.emater.mg.gov.br/portal. do?flagweb=site_tpl_queijo\&id=3622), acessado em outubro de 2019.

As normas sanitárias têm feito, entre outras coisas, que seja impedida a circulação de pessoas e que o espaço de fabricação seja afastado de outros cômodos, como da casa e do curral. ${ }^{26} \mathrm{E}$ definem com detalhes como deve ser o curral de ordenha: distância e localização em relação à queijaria, tipos de pisos e coberturas, declividades,

26 Este afastamento pode ser percebido nas fotos da Figura 1, com as antigas casas de queijo aparecendo próximas à casa/curral e as novas queijarias estando mais isoladas. 
escoamentos, pontos de água. Exigem ainda que as queijarias fiquem distantes da pocilga e do galinheiro, o que inviabiliza ou coloca a necessidade de refazer também essas construções. Termina interferindo na realização de outras atividades, até então próprias da diversificação do sistema camponês. ${ }^{27}$ Uma mudança de concepção que se volta para a lógica modernizadora de especialização produtiva e aumentos de produtividade. E que está associada a aumentos nos custos e perda de autonomia.

Nessas regiões produtoras, as casas de queijo ficam em geral muito próximas e frequentemente interligadas com o curral onde as vacas são ordenhadas, tendo em vista facilitar o transporte do leite. Mas a visão pasteuriana percebe essa proximidade como "sujeira" e "perigo", ${ }^{28} \mathrm{com}$ riscos de contaminação pela presença de lama/poeira e do estrume. Assim a lei coloca um conjunto de exigências, como a inexistência de comunicação direta e a construção de um local para a higienização pessoal e troca de roupas, para evitar o trânsito direto.

A separação entre a queijaria e o curral aumenta em muito a penosidade para o carregamento do leite, o que tem feito famílias produtoras com melhores condições financeiras colocarem, além da ordenhadeira mecânica, circuitos hidráulicos para o transporte do leite. Considerados mais limpos e seguros pelos técnicos, esses circuitos, formados por tubulações e motores, não estão isentos de riscos de contaminação, pois são difíceis de serem limpos, necessitando de água fervendo (o que aumenta custos com energia elétrica, onde ela existe) e produtos de limpeza que, por sua vez, deixam resíduos que afetam o leite e os queijos. Mas as normas sanitárias associam cada vez mais o fator humano e o uso de materiais naturais a riscos, e consideram a automação e o uso de equipamentos e materiais industrializados em si como elementos de segurança. Esses valores estão na base da formação dos técnicos de nível superior que atuam nessa área, o que os levam a enfatizar alguns riscos (considerados arcaicos e inaceitáveis) e minimizar outros (considerados como riscos assumíveis). ${ }^{29}$

27 Registre-se que uma grande parcela das famílias produtoras de queijos apresenta uma diversificação produtiva, que complementa a renda e a alimentação (das pessoas e dos animais), como a criação de porcos e galinhas, com o soro do leite (subproduto do queijo) e também café, milho, mandioca, gado de corte, venda de leite e atividades não agrícolas (Cintrão, 2016; Dupin, 2019).

28 Vale lembrar que no processamento industrial a separação em relação ao curral é total, com o leite levado das propriedades rurais para laticínios em zonas urbanas.

29 É o caso, por exemplo, dos riscos associados ao uso de antibióticos, produtos químicos (sanitizantes, inseticidas, carrapaticidas, herbicidas) e hormônios artificiais, necessários em vacas de alta produtividade, alimentadas com rações e submetidas a um maior número de ordenhas. 
No que se refere aos utensílios e equipamentos, enquanto as leis federais exigem quase tudo em aço inoxidável - material bastante caro - a lei mineira aceita outros materiais, como plásticos e a pedra de ardósia para a mesa onde se produz os queijos, reconhecendo novos materiais já utilizados em algumas regiões produtoras (ver Figura 2). Porém, mantém a interdição ao uso da madeira, exceto para as prateleiras de cura dos queijos. ${ }^{30}$

No emaranhado de dispositivos jurídico-legais da microbiopolítica, para além dos desacordos entre técnicos especializados na própria construção das normas, são comuns diferentes interpretações, com diferentes graus de desconsideração para com as práticas e saberes das famílias produtoras. Alguns fiscais exigem azulejos, outros permitem tintas laváveis; alguns exigem que tudo (inclusive o piso) seja branco, outros permitem outras cores. Há quem proíba o uso de madeira em janelas, portas e estruturas, outros só exigem que sejam pintadas. Alguns interditam prateleiras encostadas na parede. A referência à separação do espaço interno em áreas ou ambientes é associada por alguns fiscais à necessidade de construção de divisórias ou paredes internas, aumentando o custo das obras (e impraticáveis em queijarias pequenas) e piorando a circulação do ar, mas outros a interpretam apenas como alterações na disposição interna.

São recorrentes reclamações de que cada fiscal que chega à propriedade coloca novas ou diferentes exigências a partir da sua interpretação da lei, com a frequente necessidade de obras e aumento nos gastos: um local para lavar as botas, uma nova torneira, um calçamento em volta da queijaria, uma mudança de pia de lugar, a mudança de uma prateleira, a interdição de uma janela, a retirada de uma árvore que derruba folhas, etc. Um produtor comentou, com ironia, que a cada visita do fiscal ele já chama junto o pedreiro. E, frente a uma ampla e detalhada lista de exigências legais, dificilmente cumpridas na sua totalidade, cada técnico ou fiscal prioriza algumas em relação a outras, muitas vezes a partir de julgamentos morais, com forte apelo estético.

30 A interdição do uso da madeira na produção de queijos está presente em normas internacionais e é alvo de fortes controvérsias entre cientistas, com muitos trabalhos publicados a respeito (ver Cintrão, 2016). 


\section{Microbiopolítica, estética industrial e regulação sanitária: o laboratório chega às roças}

As normatizações sanitárias atingem também os corpos das famílias produtoras. Proíbem o uso de barba, esmalte nas unhas, relógios, anéis, brincos. Obrigam a realização de exames anuais de sangue (para teste de tuberculose). E exigem que as pessoas que elaboram os queijos utilizem touca, avental, luvas, máscara e botas de borracha - todos brancos, moralmente associados a uma maior higiene e segurança. Controlam assim os corpos e aproximam a imagem dos "quartos de queijo" ao ambiente de trabalho dos cientistas - o laboratório e seus fluxos -, onde sobressai a ideia de controle. Mais do que isso, numa percepção claramente marcada por uma perspectiva urbana e industrial de grande escala, associam a preparação dos alimentos - e a responsabilidade moral de comer de forma segura - com uma crescente medicalização da comida, construindo uma "estética pasteuriana", que aproxima as imagens de segurança na fabricação de alimentos aos centros cirúrgicos, onde a esterilização é máxima, como se pode ver nas Figuras 3 e 4 .

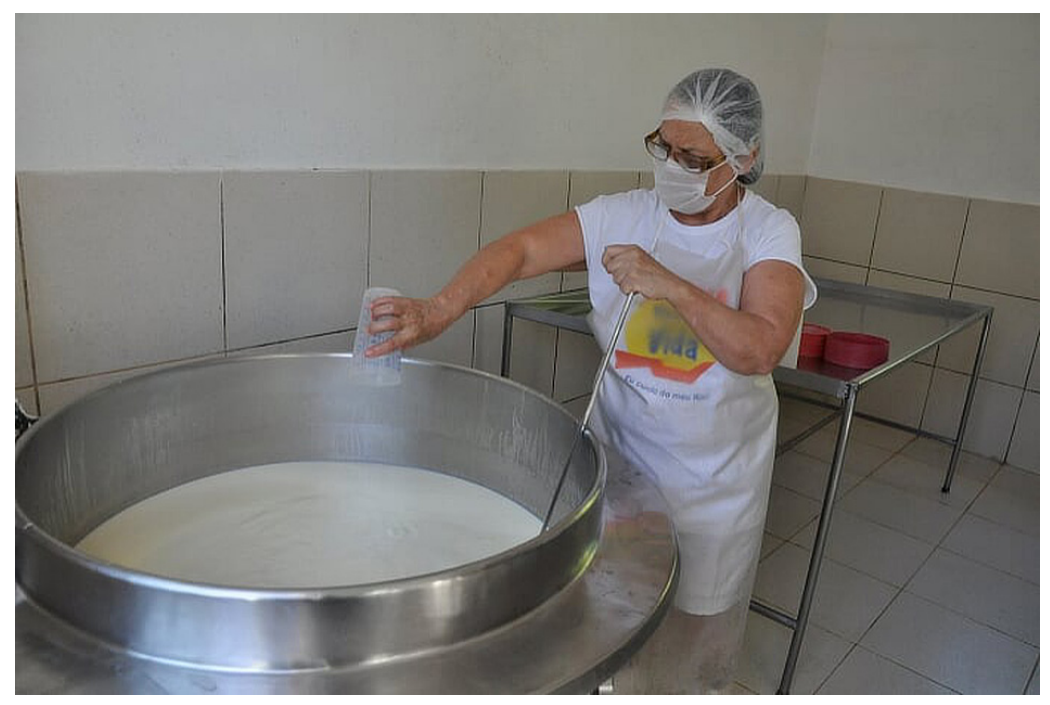

Figura 3. Interior de queijaria "cadastrada", na região da Canastra.

Foto: Leonardo Dupin, 2016. 


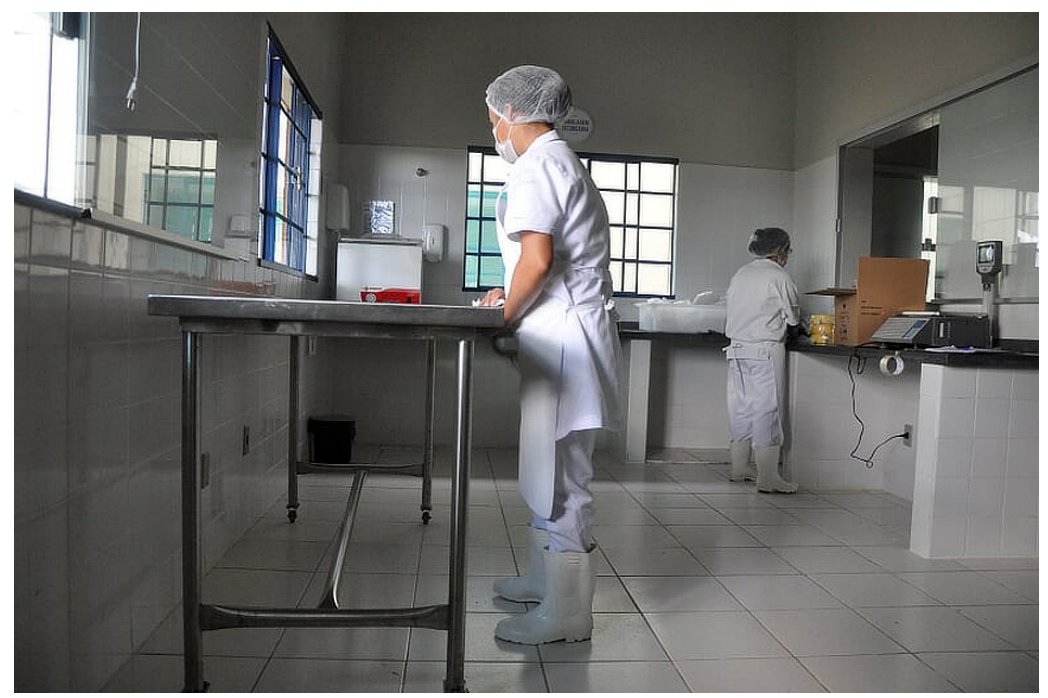

Figura 4. Área de embalagem expedição de queijos da Aprocame - Associação de Produtores de Queijo Canastra de Medeiros. Foto: Leonardo Dupin, 2016.

Assim, as condições estruturais das casas de queijo estão entre os elementos mais condenados pelos agentes sanitários e técnicos especializados, como indicadores da "baixa qualidade" e dos "riscos" dos queijos minas artesanais produzidos pela grande maioria das famílias. Essa percepção aparece em na fala de uma veterinária do Mapa, do setor responsável pela construção de normas sanitárias federais, proferida em encontro técnico organizado pelo Instituto do Patrimônio Histórico e Artístico Nacional (Iphan) em 2012:

O Ministério [da Agricultura] visitou 376 propriedades rurais produtoras de queijos artesanais do Serro, Canastra e Araxá. [...] E somente seis tinham condições realmente de estar elaborando o queijo, isso a gente falando não só a respeito da questão de estrutura, mas também com base nos resultados de laboratório que foram realizados: todos eles, a maioria dos laudos apresentavam um alto índice de contaminação microbiana. (cf. Cintrão, 2016, p. 226). ${ }^{31}$

31 Esse encontro visava a salvaguarda dos queijos artesanais. 
Note-se que numa amostragem significativa, apenas $2 \%$ das casas de queijo (seis em 376), foram consideradas como aptas a produzir os queijos, a partir das lentes da legislação sanitária e seus mecanismos disciplinares (no sentido foucaultiano), que prescrevem como deveriam ser. As normas legais, a crença no laboratório e a atitude de aversão aos "maus microrganismos" constroem uma realidade de "baixa qualidade" e de "falta de higiene" dos queijos, apesar das "qualidades" que lhe deram fama e notoriedade. E contribuem para desqualificar saberes e modos de fazer, com repercussões sobre as formas como as famílias produtoras são percebidas e percebem a si próprias, como aponta a fala de um outro fiscal do Mapa:

Aí eu comecei a fazer um trabalho de visitar [...] os produtores, perguntar por que eles não legalizavam. As pessoas tinham vergonha de te levar na queijaria, te mostravam o queijo mas nunca te levavam na queijaria. Ela era um depósito de soro, tinha rachadura, o soro fermenta, era precário, a céu aberto, não era algo que se mostrava. Elas levavam o queijo para a cidade, as pessoas adoravam, mas quem buscava eram familiares [...] Era bem escondido. (Fiscal do Mapa - Belo Horizonte, 2013).

A chegada das legislações e fiscalizações leva a uma preocupação das famílias com o que visitantes vão achar, passando a "esconder" e a "ter vergonha" de mostrar o local de fabricação, mesmo tendo seus queijos apreciados. Na população local, passam a surgir comentários morais sobre as novas queijarias (adaptadas à legislação), de que a produção está "muito melhor, mais limpa, azulejada", que "o azulejo é mais fácil de limpar e que antes era muito sujo". ${ }^{22}$ Percebe-se assim uma dominação simbólica, no sentido colocado por Bourdieu (1989), da estética urbano-industrial:

32 Vale ressaltar que no modo de fazer tradicional as paredes das casas de queijo raramente eram lavadas e não eram percebidas como "sujas". A maior atenção com o "asseio" é dada pelas famílias à banca (onde são feitos) e às prateleiras, que demandam uma lavagem cotidiana, mas com critérios distintos das normas técnicas, conforme comentaremos. As exigências de lavagem das paredes aumenta em muito o trabalho cotidiano de limpeza, que sobrecai em especial sobre as mulheres. 
Eu tive uma experiência triste, que mandaram de Brasília para Araxá, [um fiscal] do SIF de lá [Sistema de Inspeção Federal, do Mapa], fazer um levantamento dos produtores de queijo [...] eu conhecia bastante produtores e ele pediu para eu acompanhar. Ele não conseguiu fotografar nenhuma queijaria [...]. Ele falou: "Se eu mandar uma foto de uma queijaria dessa aqui para Brasília, a hora que chegar lá, o queijo, a tendência é proibir mesmo, porque não tem condição de ser fabricado nesses lugares." Isso para mim foi horroroso, porque [...] você não quer produtor que não tenha a capacidade de fazer um produto próprio para consumo. Na época eu fiquei muito triste com isso. Então eu comecei a fazer o meu queijo, eu comecei e em 2008 eu consegui a certificação [...] Eu cito o meu caso como exemplo [...] por isso, porque eu fiz tudo certinho, minha banca é inox, minha queijeira é toda azulejada, é toda forrada [...] eu ganhei cinco vezes o melhor queijo da região, então tem como fazer um produto de boa qualidade atendendo a legislação do jeito que está. (Produtor de Araxá - encontro técnico do Iphan, 2012, cf. Cintrão, 2016, p. 233, grifo nosso).

Falas como essa passam a ser comuns por parte de produtores com melhores condições econômicas, que almejam certificações sanitárias e selos de Indicação Geográfica para a venda para mercados de maior poder aquisitivo. E que buscam se distinguir da grande maioria, tendo em vista compensar os investimentos e aumentos nos custos, ou mesmo diminuir a concorrência..$^{33}$

No entanto, é possível observar, na fala desse produtor - assim como em várias outras das populações locais das regiões produtoras - um forte descolamento entre esses elementos estéticos e morais e a percepção de riscos e perigos a eles associados. Note-se que não são os agravos à saúde - pessoas que tenham adoecido ou passado mal comendo os queijos - que são apontados como motivo de vergonha ou preocupação, mas "a foto" da casa de queijo, sem azulejo e sem mesa de inox. O queijo até pode ser apreciado, mas o local de fabricação que não segue as especificações legais não pode ser mostrado, pois é considerado como “impuro" e, portanto, "perigoso” (no sentido de Douglas, 1976),

33 Dupin (2019) analisa as dinâmicas envolvidas na valorização dos queijos por esses novos produtores, vários deles patronais (que não trabalham diretamente na produção dos queijos, feitos com mão de obra assalariada) e/ou de origem urbana (ou com formação universitária e fontes de renda não rurais). 
por não corresponder à visão de ordem e aos valores e referências simbolicamente dominantes.

Em exemplo semelhante, Roseman (2004), analisando a regulação da "comida caseira" na Galícia, observa que os valores associados à implantação das "leis hiper-higiênicas", num ambiente social e econômico global que intensificou os mecanismos institucionais de monitoramento da segurança sanitária, criam um espaço discursivo que suscita suspeitas de que a "ignorância" dos produtores de pequena escala levaria à produção de alimentos contaminados e potencialmente perigosos para a saúde humana. A autora aponta o impacto que essas regulamentações têm sobre as subjetividades daqueles que estão envolvidos intimamente na produção de alimentos. Observa ainda que projetos regulatórios podem levar a uma estigmatização de técnicas de produção profundamente enraizadas em relações rurais e práticas cotidianas, resultando não apenas em consequências diretas (multas e exigências de ajustes), mas reforçando a estigmatização cultural dos camponeses, apresentados como "apegados a métodos antigos" de cultivo e processamento de alimentos.

Cruz (2012) observa que, mesmo que em alguns casos se crie uma imagem do rural como puro e saudável frente às visões de deterioração urbana, há representações bastante difundidas entre técnicos especializados e entre a população de grandes centros urbanos, do rural como sujo e pouco civilizado, ligado a sujeiras como poeira, lama, estrume e suor humano. Essa perspectiva é fortemente reforçada pela visão higienista voltada para produções industriais de grande escala, que considera a terra como suja e o cimento como limpo, assim como materiais naturais (barro, palha, madeira) como sujos e perigosos, frente a materiais industriais (inox, azulejos, plásticos) inerentemente mais limpos, porque mais laváveis.

Diante desse contexto de estigmatização camponesa, vale lembrar o estudo clássico de Douglas (1976), que aponta que as definições de higiene e pureza (que se associam à noção de perigo) estão carregadas de interpretações e valores simbólicos, envolvendo uma visão de ordem e desordem, relacionada a diferentes elementos do sistema social. Segundo a autora, a impureza nunca é um fenômeno único, implicando, por um lado, a existência de um conjunto de relações ordenadas e, por outro, a subversão dessa ordem. A impureza é assim o subproduto de uma organização e de uma classificação da matéria, na medida em que diz respeito a qualquer coisa que não está no seu lugar. Ordenar pressupõe repelir os elementos não apropriados (Douglas, 1976, p. 30). 
No caso em análise, a imagem da "segurança" tornou-se tributária do modo de produção industrial, com a associação de ordem e higiene a esse modelo. E qualquer elemento que esteja fora dessa ordem é considerado como impureza, justificando repreensões, apreensões e multas. E afetando a reputação das famílias produtoras, mesmo quando seus queijos são reconhecidamente bons.

\section{A abrangente e sofisticada percepção local sobre "boas práticas" de produção}

Você tem que entrar na queijaria e esquecer o mundo lá fora. Esquecer seus problemas do lado de fora, esquecer sua vida lá fora e aí você consegue produzir um queijo bom. O queijo é um alimento vivo, né? Isso aqui, tudo que é negativo passa para ele e tudo que for positivo passa também. Então se você traz seus problemas lá de fora aqui para dentro você vai passar para o seu queijo [...], se trabalha na correria não dá muito certo não, você tem que vir pra cá e esquecer seus problemas lá fora [...] Tem que ter dedicação. (Produtor da Canastra, 2016, cf. Dupin, 2019, p. 325).

Enquanto a microbiopolítica volta-se para estruturas, materiais e controles visando a assepsia, para as famílias produtoras o "zelo" e o "capricho" traduzem um conjunto abrangente de cuidados que perfazem um "bom produto" e um "bom produtor". Cruz (2012) argumenta que a noção de "capricho" corresponde a "boas práticas de fabricação" locais, que são em geral suficientes para fazer um alimento "seguro", pois embutem conhecimentos tácitos, socialmente construídos ao longo de décadas na prática cotidiana de produção, comercialização e consumo dos queijos, sempre interagindo com novos conhecimentos e informações. Mas muitos desses conhecimentos são desconsiderados pelas normas sanitárias - e pelos técnicos especializados - que carregam uma visão urbano-industrial de profilaxia, que leva a uma associação do meio rural e natural, assim como de agricultores e pessoas pobres ou com menor escolarização, a riscos e perigos, com definições de higiene e pureza carregadas de interpretações e valores simbólicos.

Por exemplo, os agentes administrativos e técnicos especializados associam o "inchaço" dos queijos - problema que eventualmente acontece na produção 
e é associado à contaminação microbiana - quase exclusivamente à "falta de higiene", seja na ordenha (pela presença de barro ou esterco, na falta de limpeza do úbere da vaca), nos instrumentos e utensílios mal lavados, ou mesmo em quem faz o queijo (não lavar as mãos, não tomar banho ou usar roupas sujas). As múltiplas possibilidades de causas levantadas pelos técnicos são todas ligadas à percepção do ambiente e das pessoas como potencialmente "sujos", com forte conotação moral. Uma percepção que reafirma a necessidade de uma maior vigilância (no sentido foucaultiano) e reitera a incapacidade dos produtores e a necessidade da ciência e de técnicos especializados, únicos capazes de prescrever detalhadamente o que deve ser feito e como, ${ }^{34}$ colocando a necessidade de cursos de capacitação para "aplicação de boas práticas" e de monitoramento dos queijos através de laboratórios e exames microbiológicos.

Para as famílias produtoras, embora o "capricho" tenha como um dos componentes importantes o "asseio" e a "limpeza", considerados importantes para a obtenção de um "bom queijo" (ou de um "queijo de massa fechada") -, o que legitima em parte o discurso técnico e as análises laboratoriais - as percepções sobre as causas do inchaço não se atêm a aspectos de higiene. O "asseio" independe de estruturas e envolve alguns cuidados básicos, como lavar bem os utensílios e equipamentos utilizados para a ordenha e para a fabricação, filtrar o leite com um pano, entre outros. Mas as "boas práticas" locais envolvem vários outros aspectos, como cuidados na fabricação ("a massa do queijo bem espremida", "o queijo zelado") e reciprocidades que perpassam a terra, as plantas, os animais, os artefatos e as pessoas: "o pasto vedado", "o boi sadio". Um casal de produtores comentou que não entendia como um vizinho poderia estar legalizado "se os animais da fazenda eram mal zelados".

Antes da chegada do laboratório e dos técnicos especializados, o estufamento ou inchaço dos queijos (que pode levar ao seu descarte) já era considerado localmente como um problema, evidenciado pelos termos utilizados, como o queijo "atrapalhar" ou "zangar". Quando isso acontece, algumas medidas são tomadas. A primeira, largamente difundida nessas regiões produtoras,

34 Várias dessas medidas são detalhadas nas normas técnicas legais, como na portaria do IMA n 523/2002 (Instituto Mineiro de Agropecuária, 2002b), que trata especificamente das "condições higiênico-sanitárias e boas práticas de manipulação e fabricação do queijo minas artesanal". Seu capítulo VII trata especificamente "da higiene pessoal e do requisito sanitário", indicando inclusive "a forma correta de lavar as mãos". 
é substituir o "pingo", buscando num parente, compadre ou vizinho um novo fermento para a elaboração do próximo queijo. E tentar descobrir as possíveis causas, incorporando novos conhecimentos, mas não necessariamente abandonando práticas anteriores, entre as quais se incluem rezas e benzimentos, conforme depoimento de um produtor "cadastrado" da região da Canastra:

A primeira coisa quando zanga o queijo eu vou lá na ordenha ver se tem alguma falha minha, se ficou alguma parte mal higienizada, exame nas vacas para ver se tem algum peito ruim, se eu não encontrei nada disso, eu pergunto a Maria [esposa] sobre os latões, formas, banca e tal e tal, se está tudo bem lavado. Aí [depois disso] eu já vou para a parte de oração, espiritual. Porque primeiro a gente tem que caçar as coisas que a gente vê. Porque eu considero assim, a bactéria é igual à fé da gente, a gente sabe que existe, mas a gente não vê ela. [...] Então a gente tem que correr atrás porque a gente não está vendo a bactéria, mas às vezes a gente errou e contaminação está ali. Aí eliminou essa parte de contaminação eu vou para outra coisa [a reza]. (Produtor da Canastra, 2016, cf. Dupin, 2019, p. 341).

E embora em alguns casos de inchaço os produtores constatem que houve mesmo algum descuido - que pode ou não ser associado à "falta de higiene" há uma percepção bastante mais abrangente das possíveis causas, inclusive algumas relacionadas com as próprias exigências da legislação ou à incorporação de novas tecnologias, como, por exemplo, o uso de sanitizantes e detergentes, cujos resíduos são apontados como desestabilizando a produção. Outro produtor observou que "antes do cadastramento" havia apenas duas ou três razões para o queijo inchar e "atualmente" - após alterações impostas pela legislação e incorporações de técnicas industriais - há muito mais motivos. Muitos "cadastrados" associam o azulejo e a falta de ventilação, assim como o excesso de esterilização, a elementos que favorecem o inchaço. Há uma percepção mais fina, de que qualquer alteração no ambiente (e não apenas a "sujeira") pode afetar os queijos. ${ }^{35}$

35 Essa percepção dos produtores é explicada cientificamente por pesquisadores "pós-pasteurianos" (conforme os nomeia Paxson, 2013) como interferências no equilíbrio microbiológico, dado que os queijos de leite cru envolvem centenas de espécies de microrganismos lácteos interagindo entre si. 
O próprio cloro, visto como essencial pelos higienistas por suas propriedades esterilizantes, é em grande medida percebido pelas famílias produtoras como prejudicial aos queijos, embora concordem que a água clorada pode ser útil para a lavagem dos panos e das formas de plástico. ${ }^{36}$ Mas o cloro não é visto como única alternativa: o soro do leite, subproduto do queijo e rico em microrganismos (ao contrário do cloro, que esteriliza) é apontado como útil para lavar os queijos e alguns utensílios e equipamentos (como formas e bancas). A fala de um comerciante de queijos, de família de produtores, aponta as diferenças entre as normas hipersanitárias e os padrões locais:

O queijo até gosta às vezes de uma banca suja, mas dele mesmo. [...] O queijo não gosta que lava a banca [com cloro], não. Ele tem uma bactéria que é dele. [...] Pra lavar o queijo e ficar gostoso lava o queijo no próprio soro.

No mesmo sentido, um outro produtor observou que a "sujeira do próprio queijo é boa para o queijo", criticando as exigências de excesso de limpeza nas queijarias.

Entre as "boas práticas" valorizadas pelos produtores estão as rezas no início de fabricação dos queijos, o corte da coalhada em forma de cruz, gesto que retribui a benção recebida de ter a matéria-prima para a fabricação, numa relação de respeito e dádiva com entidades sagradas. As formas de agradecimento e devoção estão presentes em várias propriedades, através de crucifixos e orações escritas que ocupam parte das paredes e portas das queijarias.

O queijo está dando problema e você faz teste numa vaca e faz teste na outra, você rastreia de um lado e procura do outro e num encontra nada, você corre para o benzedor. Aqui pertinho tem dois senhores, dois irmãos vizinhos, excelentes benzedores. Benze tudo, na verdade o benzedor é um cara que tem o poder da oração muito forte, é um cara que tem o dom de Deus e que Deus aceita o poder

36 A exigência de cloração da água é um dos focos de resistências e conflitos, dado que a maioria das propriedades têm nascentes e a qualidade da água é um dos distintivos em algumas das regiões produtoras. Mas há por parte dos técnicos um receio da sua contaminação microbiológica por animais silvestres, insetos ou pelo próprio gado. 
daquela oração de quem está pedindo. É uma pessoa que é um intermédio, que tem umas palavras santas. Não tem alguém que não tenha pedido [um benzedor] aqui na região. Queijo é um produto assim muito invejado. O queijo bom é na verdade um queijo invejado. [...] E a oração é uma defesa de uma inveja. (Produtor da Canastra, cadastrado, abril de 2016).

Essas formas de cuidado são consideradas por eles tão necessárias quanto o saber "técnico", com o saber prático e o simbólico se fundindo e o trabalho de fabricação constituindo um modelo cosmológico. Mas essas práticas não são reconhecidas pelas normas legais e são desprezadas pela visão técnico-científica, que as considera como atraso, ignorância ou precariedade, associando-as a riscos e perigos.

Apenas o processo de esterilização e de "artificialização", que está na base da industrialização e viabiliza produções em grandes escalas, é visto como positivo. Outro exemplo refere-se às contaminações dos queijos com estafilococos, microrganismos associados a infecções nas tetas das vacas (mamite), normalmente atribuías pelos técnicos especializados à "falta de higiene na ordenha". Para contorná-las, as normas sanitárias exigem um conjunto de medidas sanitizantes: mudanças estruturais no curral (para torná-lo mais "lavável"), maior limpeza do úbere e uso de iodo nas tetas das vacas. Já as famílias produtoras observam um aumento da suscetibilidade das vacas à mamite, causado pelas técnicas modernas voltadas para aumentos de produtividade, como a especialização das raças leiteiras, as novas formas de alimentação do gado (silagens e rações à base de grãos), o aumento do número de ordenhas diárias, a separação entre o bezerro e a vaca. Apesar de aumentarem os riscos de incidência de estafilococos, essas mudanças são consideradas positivas pelos técnicos especializados, que buscam contornar os novos riscos tecnológicos reafirmando e aprofundando as medidas de assepsia: testes diários do leite com reagentes comprados, uso de antibióticos e descarte do leite. $\mathrm{E}$ mais exames de laboratório, como um instrumento biopolítico de controle à distância. Cruz (2012) observa que práticas percebidas pelos técnicos como precariedade e atraso, como deixar o bezerro começar a mamar logo antes da ordenha (para o leite da vaca "descer") e também após a ordenha (para esgotar resto de leite das tetas), podem ser consideradas "boas práticas" que evitam a mamite. 


\title{
Estruturas, qualidade dos queijos e riscos à saúde - desacordos entre sistemas classificatórios
}

\begin{abstract}
Eu não estou criticando não, eu estou colocando só a nossa parte, com relação à banca de madeira que eu sou defensor e tenho certeza que muita gente vai me ajudar. Aqueles que quiserem usar de inox, use de inox, mas não proíba a gente de usar a de madeira, porque nós precisamos de um habitat bem simpático ao queijo. A mesma coisa é o joão-de-barro, a casa dele é de barro. Põe um ninho certificado lá para ver se ele entra nele. Ele não entra [...]. (Produtor do Serro encontro técnico do Iphan, 2012, cf. Cintrão, 2016, p. 231).
\end{abstract}

Os técnicos da Emater-MG e os fiscais sanitários são praticamente unânimes em afirmar que a "qualidade" do queijo melhorou muito após a intensificação das fiscalizações e difusão das "melhorias" nas casas de queijo. E é possível perceber, conforme comentado, a força simbólica da estética urbana e industrial dominante, que leva famílias produtoras a referendarem as novas queijarias como "mais bonitas" e mais "fáceis de limpar" e a considerarem materiais e equipamentos industrializados como superiores.

Mas há, por outro lado, inúmeras manifestações de produtores, atravessadores e consumidores locais que indicam desacordos com as exigências sanitárias, como nessa fala que faz uma analogia com o joão-de-barro e menciona que o azulejo e o inox não necessariamente são melhores do que o barro e a madeira para a "vida dos queijos", relativizando e denunciando a imposição da estética industrial e de um modelo único de produção.

Da mesma forma, são frequentes as reclamações de produtoras e produtores "cadastrados" que observam que, após as reformas, o ambiente das queijarias ficou pior, por inúmeras razões. Por exemplo, que ficam mais quentes e abafadas (para os queijos e para quem os faz), devido às intervenções sanitizantes que interditam janelas e limitam a circulação do ar para evitar possíveis contaminações. São comuns comentários de que o azulejo "não deixa a casa de queijo respirar" e que quando é mais ventilada o queijo seca mais rápido e fica melhor. Alguns chegam a dizer que é possível produzir um bom queijo "até embaixo de uma árvore", num ambiente fresco e ventilado, que pode ser "até melhor que uma sala azulejada". 
E são vários os comentários que relativizam a superioridade dos queijos produzidos nas queijarias legalizadas, como observações de que "apesar da queijaria ser muito simples e rústica, os queijos são bons demais, até melhor do que os de algumas pessoas da associação". Ou de que "estão carecas de ver queijo do IMA [de produtores cadastrados] muito pior do que o deles". Ou que já viram queijarias com parede de bambu e com chão batido que os queijos eram muito bons. E que "a preocupação da Vigilância [Sanitária] é com o prédio, não com a qualidade do queijo". De certa maneira, a seguinte fala sintetiza percepções presentes nas regiões produtoras:

Tem casinha ruim que o queijo é bom e [casinha ruim] que é ruim. E tem casinha toda azulejada que o queijo é bom e que é ruim. Bom e ruim é como um restaurante: a comida até pode ser boa, mas quando você vê a cozinha está tudo feio e bagunçado. (Atravessador da Canastra, em conversa informal, 2014).

No entanto, pela força da estética urbana e industrial, casas de queijo fora das exigências sanitárias tendem a ser cada vez mais ilegalizadas.

Outra interferência da legislação sanitária nas práticas costumeiras se estende às formas de transporte e comercialização dos queijos, com um conjunto de exigências e interdições de infraestruturas, materiais e equipamentos, como a obrigatoriedade de refrigeração e do uso de embalagens plásticas e rótulos, suscitando também reações e desacordos.

No Mercado Central de Belo Horizonte, assim como em vários outros mercados em Minas Gerais, a grande maioria dos queijos artesanais são vendidos empilhados sobre o balcão das lojas, sem embalagens ou marcas e sem refrigeração. Muitos são vendidos fracionados e partidos ao meio, o que permite aos consumidores mais atentos ver detalhes dos queijos, por exemplo, se estão "tampados" (sem furos) ou rendados (com pequenos furos), dessorados ou ainda úmidos, podendo ainda provar o teor de sal e escolher o sabor que mais lhe agrada. Os comerciantes explicam que são estes o que os consumidores identificam como o "queijo da roça" ou o "queijo caipira", o que indica uma construção cultural objetivada ou materializada que expressa unidades de significado, pontuando tempos e lugares evocados, que dá significância e ordem ao mundo vivido.

Mas as normas sanitárias impõem a refrigeração (inclusive no transporte), assim como embalagens plásticas e rótulos, colocando os queijos fora dessas 
condições como ilegais, perigosos e "sem identidade". São comuns - entre produtores, comerciantes e consumidores - as reações que condenam as embalagens plásticas, por alterarem ou mesmo "asfixiarem" os queijos, interrompendo seu desenvolvimento e fazendo-o "amargar":

Eu sempre vendi queijo no balcão. O pessoal aqui gosta daquele queijo ali sem congelar e embalar, que eles falam, sabe? Porque você vai no supermercado e compra ele no plástico e ele está ardido. Não é um queijo que você come ele com gosto, aquele queijo que tem o paladar gostoso. O queijo enrolado no plástico é outro queijo. (Fala de comerciante, cf. Dupin, 2019, p. 122-123).

E a obrigatoriedade de refrigeração - que exige investimentos e custos -, na medida em que interrompe ou retarda a maturação, é apontada inclusive por cientistas como contraditória com as leis que exigem tempos mínimos de cura para queijos de leite cru, considerando que quanto mais curado menor o risco de agravos à saúde.

E a despeito dos consumidores serem descritos por técnicos e fiscais sanitários como tolos e incapazes de garantir sua própria segurança ao comprarem produtos "potencialmente perigosos" e "desprovidos de higiene", ou ainda pouco capazes em termos gastronômicos (por preferirem queijos brancos e menos maturados, com menos sabor), existe grande habilidade e experiência por parte de parcela significativa dos consumidores em avaliar as características desses queijos, de modo a escolher qual consumir, o que torna muitas vezes menos importante identificar o fabricante. ${ }^{37}$ Para eles, a "falta de padrão", condenada pelas visões industriais, é considerada como uma vantagem, com uma diversidade que atende a vários gostos e situações: mais furadinho (e azedinho) para comer com doce, mais curado para o pão de queijo, etc.

Há nas regiões produtoras critérios e categorias culturalmente compartilhados entre famílias produtoras e consumidores, que incluem outros sentidos de "qualidade" e "segurança". Por exemplo, para os fiscais e técnicos

37 Ainda mais porque, quando produzido em condições naturais, ou seja, em queijarias com ventilação natural e com vacas alimentadas a pasto (e não com rações balanceadas de grãos), os queijos do mesmo fabricante não são sempre iguais, respondendo às variações das estações do ano e do ambiente em geral. 
especializados, a presença de furinhos é considerada bastante perigosa, porque associada a altos índices de contaminação por coliformes fecais, atestados pelos exames laboratoriais. E embora os critérios de qualidade locais associem "bons queijos" àqueles de "massa fechada" (que não apresenta olhaduras), legitimando de certa maneira o laboratório, os riscos associados são relativizados pela existência de um mercado não desprezível para os queijos furadinhos, ${ }^{38}$ que tendem a ser mais baratos.

Famílias produtoras, comerciantes e consumidores dos queijos minas artesanais desconfiam dos perigos anunciados pelos técnicos e fiscais, como indicam várias falas irônicas, como "se este queijo fizesse mal teríamos uma epidemia de queijo em Minas" ou, ainda, "o perigo de comer esse queijo é você viver muito". $\mathrm{E}$ a grande quantidade de queijos fora das especificações legais (e condenáveis pelos exames laboratoriais), que são produzidos, vendidos e consumidos, indica que as práticas locais têm-se revelado hábeis em controlar e garantir a "inocuidade" do alimento, não no sentido atribuído pela legislação sanitária (de ausência de microrganismos), mas no sentido de evitar agravos à saúde. Sinaliza, ao mesmo tempo, uma provável inadequação das normas e indicadores microbiológicos àquela realidade. Mas seu "biopoder" vem levando a crescentes ilegalizações e exclusões (além de aumentos nos custos), restringindo a circulação dos queijos e também as opções de escolha dos consumidores, reforçando a concentração industrial no setor alimentício.

\section{Conclusões}

Este artigo analisou a regulação sanitária dos queijos artesanais em Minas Gerais, que se impõe como uma biopolítica (Foucault, 2008) que busca controlar à distância a produção local, conformando um emaranhado legal que conjuga dispositivos jurídico-legais (proibições), da ordem da vigilância (que prescrevem em mínimos detalhes como deve ser essa produção) e da segurança (através do laboratório e da construção de parâmetros microbiológicos). Essa

38 É comum, por exemplo, ouvir de atravessadores locais o comentário de que "paulista não entende de queijo", referindo-se ao fato de que em alguns mercados de São Paulo há uma preferência pelos "queijos furadinhos", considerados os verdadeiros "queijos da roça". 
governamentalidade, que tem como ideal o modelo industrial de produção e conservação de alimentos automatizado e em grande escala, que orienta a construção de códigos sanitários globais, tem contribuído para construir uma imagem depreciativa dos queijos feitos nas roças, fortemente enraizados culturalmente e com um mercado de consumo que extrapola as regiões produtoras.

A imposição de leis hiper-higiênicas levantam nas sociedades urbanas, ditas modernas, suspeitas de que populações de perfil camponês estão produzindo alimentos contaminados e com "falta de segurança alimentar". Buscamos apontar que essas definições - que se associam à noção de perigo e estão carregadas de interpretações e valores simbólicos - envolvem uma visão de ordem e desordem (Douglas, 1976) intrinsicamente associada ao modelo industrial de produção de alimentos - incluindo o laboratório, um dos elementos centrais de controle. Nessa biopolítica - chamada por Paxson (2013) de microbiopolítica - que se constrói como fonte de poder que controla condutas de seres humanos através da "germofobia", qualquer coisa/fator que esteja fora da ordem industrial é considerado pelos técnicos e fiscais como impureza, se colocando como elemento importante de dominação simbólica da população das regiões produtoras, com grande ressonância junto a consumidores de grandes centros urbanos.

As imposições legais - que têm convertido, por exemplo, os "quartos de queijo" em "queijarias", espaço de especialização e controle - têm implicado - para além de gastos financeiros e aumentos nos custos de manutenção - instrumentos e mecanismos de governamentalidade e biossegurança, produzidos a partir de infraestruturas globais da tecnociência, com forte influência de corporações internacionais, que se concretizam de forma autoritária, sem dialogar com saberes e práticas locais. Se estabelecem pela força (através de multas e apreensões), por imposição econômica (relacionada à dependência de tecnologias externas à propriedade) ou/e sendo absorvidas localmente como "obrigação moral" (que privilegia inserções de origem externa como parâmetro de civilidade, frente a matrizes de racionalidade locais).

Tendo como referência uma estética industrial, tais normatizações associam elementos naturais como ameaça e aproximam a imagem da produção de "alimentos seguros" àquela do laboratório e dos centros cirúrgicos, onde a esterilização é máxima. No caso dos queijos, além dos custos econômicos, cada detalhe exigido das famílias produtoras converte-se em alterações nos modos 
de fazer e nas rotinas de trabalho, interferindo também na "vida do queijo". Porém, as exigências legais geram também reações que revelam assimetrias de poder na legitimação de discursos, mas também desacordos sobre modos de vida e sistemas classificatórios.

Apontamos que as populações locais demonstram um sofisticado conhecimento, trazendo questionamentos e caminhando em sentido contrário de processos e instâncias multinacionais, que se constroem como uma política colonial. Por deterem saberes e suas próprias racionalidades, essas populações não são passivas diante das imposições da estética urbana e industrial e fazem emergir suas percepções. Na busca de sobreviver e de produzir um "bom queijo" - seguro para o consumo - centram-se menos em estruturas físicas e mais nos cuidados - não apenas com a higiene, mas com um conjunto de elementos que envolvem, por exemplo, rezas e benzeções, consideradas por elas igualmente importantes e eficazes no processo produtivo.

Ao não diferenciar escalas e modelos de produção, ao isolar e superestimar determinados fatores de risco em relação a outros, as legislações sanitárias dos alimentos terminam reforçando padrões industriais de produção e consumo e "reprimindo" culturas alimentares e modos de vida de populações camponesas, sem necessariamente estar com isso trazendo maior proteção à saúde da população.

\section{Referências}

BOURDIEU, P. O poder simbólico. Lisboa: Difel, 1989. (Coleção Memória e Sociedade). BRASIL. Ministério da Agricultura, do Abastecimento e da Reforma Agrária. Portaria nº 146, de 7 de março de 1996. Diário Oficial da União, Brasília, p. 3977, 11 mar. 1996.

CINTRÃO, R. P. Segurança, qualidade e riscos: a regulação sanitária e os processos de (i)legalização dos queijos artesanais de leite cru em Minas. 2016. Tese (Doutorado em Ciências Sociais em Desenvolvimento, Agricultura e Sociedade) - Instituto de Ciências Humanas e Sociais, Universidade Federal Rural do Rio de Janeiro, Rio de Janeiro, 2016.

CINTRÃO, R. P. Segurança alimentar, riscos, escalas de produção - desafios para a regulação sanitária. Vigilância Sanitária em Debate: Sociedade, Ciência \& Tecnologia, v. 5, n. 3, p. 3-13, 2017. 
CRUZ, F. T. Produtores, consumidores e valorização de produtos tradicionais: um estudo sobre qualidade de alimentos a partir do caso do queijo serrano dos Campos de Cima da Serra - RS. 2012. Tese (Doutorado em Desenvolvimento Rural) - Faculdade de Ciências Econômicas, Universidade Federal do Rio Grande do Sul, Porto Alegre, 2012.

CRUZ, F. T.; SCHNEIDER, S. Qualidade dos alimentos, escalas de produção e valorização de produtos tradicionais. Revista Brasileira de Agroecologia, Porto Alegre, v. 5, n. 2, p. 1-18, 2010.

DIAS, J. C. Uma longa e deliciosa viagem: o primeiro livro da história do queijo no Brasil. São Paulo: Barleus, 2010.

DOUGLAS, M. Pureza e perigo: ensaio sobre as noções de poluição e tabu. São Paulo: Perspectiva, 1976.

DUPIN, L. V. A vida dos queijos mineiros: uma etnografia multiespécie. 2019. Tese (Doutorado em Ciências Sociais) - Instituto de Filosofia e Ciências Humanas, Universidade Estadual de Campinas, Campinas, 2019.

ESCOBAR, A. Encountering development: the making and unmakig of the Third World. Princeton: Princeton University Press, 1995.

FOUCAULT, M. Em defesa da sociedade: curso no Collège de France (1975-1976). São Paulo: Martins Fontes, 2005.

FOUCAULT, M. Segurança, território e população: curso no Collège de France (19771978). São Paulo: Martins Fontes, 2008.

GARCIA-PARPET, M. F. Patrimonialização de produtos alimentícios na França: construções simbólicas e reinvenção do passado. In: WOORTMANN, E.; CAVIGNAC, J. (org.). Ensaios sobre a antropologia da alimentação: saberes, dinâmicas e patrimônios. Natal: EDUFRN; Brasília: ABA, 2016. p. 493-543.

INSTITUTO MINEIRO DE AGROPECUÁRIA. Portaria nº 518, de 14 de junho de 2002. Dispõe sobre requisitos básicos das instalações, materiais e equipamentos para a fabricação do queijo minas artesanal. Belo Horizonte, 2002a. Disponível em: http:// www.ima.mg.gov.br/files/1667/Ano-2002/17261/Portaria-n\%C2\%BA-518,-de-14-de-junho-de-2002.pdf. Acesso em: 15 maio 2019.

INSTITUTO MINEIRO DE AGROPECUÁRIA. Portaria nº 523, de 3 de julho de 2002. Dispõe sobre as condições higiênico-sanitárias e boas práticas na manipulação e fabricação do queijo minas artesanal. Belo Horizonte, 2002b. Disponível em: http:// www.ima.mg.gov.br/files/1667/Ano-2002/17267/Portaria-n\%C2\%BA-523,-de-03-de-julho-de-2002.pdf. Acesso em: 15 maio 2019.

LATOUR, B. The pasteurization of France. Cambridge: Harvard University Press, 1993. 
MINAS GERAIS. Lei n. 14.185, de 31 de janeiro de 2002. Dispõe sobre o processo de produção do Queijo Minas Artesanal e dá outras providências. Diário Oficial do Estado de Minas Gerais, Belo Horizonte, p. 3, 1 fev. 2002.

PAXSON, H. The life of cheese: crafting food and value in America. Berkeley: University of California Press, 2013.

PLOEG, J. D. Camponeses e impérios alimentares: lutas por autonomia e sustentabilidade na era da globalização. Porto Alegre: Ed. UFRGS, 2008.

RIBEIRO, G. L. Poder, redes e ideologia no campo do desenvolvimento. Novos Estudos CEBRAP, n. 80, p. 109-125, 2008.

ROSEMAN, S. Bioregulation and comida caseira in rural Galicia, Spain. Identities: Global Studies in Culture and Power, v. 11, n. 1, p. 9-37, 2004.

WEST, H. G. Food fears and raw-milk cheese. Appetite, v. 51, n. 1, p. 25-29, 2008.

Recebido: 30/06/2019 Aceito: 05/09/2019 | Received:6/30/2019 Accepted: 9/5/2019 